\title{
DETECTION OF METAL-BASED SOLID PARTICLES IN BIOLOGICAL MATERIAL FROM THE MALE REPRODUCTIVE SYSTEM
}

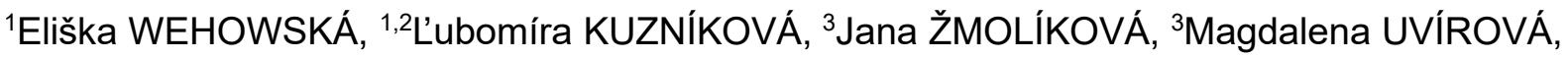 \\ ${ }^{3,4}$ Jana DVOŘ́́ČKOVÁ, ${ }^{2}$ Kristina ČABANOVÁ \\ ${ }^{1}$ Nanotechnology Centre, VSB - Technical University of Ostrava, Czech Republic, EU, \\ eliska.wehowska.st@vsb.cz, lubomira.kuznikova@vsb.cz \\ ${ }^{2}$ Centre for Advanced Innovation Technologies, VSB - Technical University of Ostrava, Czech Republic, EU, \\ lubomira.kuznikova@vsb.cz; kristina.cabanova@vsb.cz \\ ${ }^{3}$ CGB Laboratory, Ostrava, Czech Republic, EU, \\ zmolikova@pathology.cz, uvirova@pathology.cz,dvorackova.mobil@pathology.cz \\ ${ }^{4}$ Faculty of Medicine, University of Ostrava, Czech Republic, EU, \\ dvorackova.mobil@pathology.cz
}

https://doi.org/10.37904/nanocon.2019.8576

\begin{abstract}
This pilot study deals with the detection of metal-based solid particles in the human ejaculate and their possible connection with infertility. Ten samples provided by cytogenetics department, CGB Laboratory, a.s. in Ostrava - Vítkovice, were analysed by scanning electron microscopy with energy dispersive X-ray spectroscopy (SEM/EDS) and Raman microspectroscopy. Metal-based particles, particularly those containing iron, aluminium, copper, zinc, chromium, titanium and nickel, were detected in the samples. At the same time, titanium compounds and calcium carbonate were found. Many of these substances have already been shown to have a negative effect on the living organism. Based on the information found, there might be some dependence between the presence of solid metal particles in the ejaculate and male fertility impairment.
\end{abstract}

Keywords: Male infertility, metal based solid particles, scanning electron microscopy, Raman microspectroscopy

\section{INTRODUCTION}

Male infertility is one of the current problems with the reproduction of the human population. One of the sources of the men infertility is less count of sperms in the ejaculate. The number of sperms in the ejaculate variates individually, the interval between 20 and 300 million sperm in millilitre is considered as normal. If the sperm count is less than 10 million, it can be related to fertility problems [1]. Currently, the amount of sperm in the ejaculate of men is rapidly decreasing. Healthy men have about $20-30$ million sperm in their ejaculate, cases with 60 million sperm are rare [2]. Decreased sperm counts might be caused due to mumps in puberty, hormonal disorders, exposure to radiation or toxic chemicals, ingestion of alcohol, tobacco or other drugs, or e.g. wearing tight underwear [1]. Problems with ejaculation itself may be caused, for example, by erectile dysfunction, nerve damage, premature ejaculation or some medications [3]. The most common reason of infertility is deformation of a sperm. Approximately $70 \%$ of all infertility cases are caused by poor sperm motility and a high proportion of abnormal sperm [2].

Up to $25 \%$ of infertile men with low mobility and poor sperm morphology tend to have higher levels of fragmented DNA than men with the normal semen parameters. DNA fragmentation is characterized by breaks in one or both strands of DNA, often presented in the ejaculate of subfertile (decreased fertility) men $[4,5]$. Often even inexplicable infertility in men with normal sperm motility and morphology can cause a higher degree 
of DNA fragmentation. Sperm cells that have broken DNA are not able to fertilize the egg cell or does not work properly in embryo development, and also may be source of spontaneous abortion [5].

The effect of various chemicals on spermatogenesis is already known [1]. Man is exposed to various particles nearly daily due to the fact they are a commonly part of everyday items. For example, titanium dioxide in the form of micro and nanoparticles is being used in cosmetics, packaging materials, pharmaceuticals, but also in coatings [6].

Nanoparticles (NPs) can enter the human body through various ways. One of the key pathways of NPs entry is inhalation. People inhale more than 10 billion particles every day. Thus, inhaled particles can be distributed throughout the body via blood, along the olfactory nerve, etc. [7]. Secondly, micron and submicron particles can penetrate the human body through skin. Human skin is the largest organ, the skin area is about $1.5-2$ $\mathrm{m}^{2}$, yet it is a very strong protective barrier, so entry through it is not so frequent [8]. Oral exposure is another way for micro and nanoparticles how to enter the human body. The number of particles entering the human body through these pathways is about $10^{12}$ to $10^{14}$ per day. Most of these particles are silicate and titanium dioxide particles [9]. Due to the amount, size and chemical composition, these particles they can cause many health problems, including infertility. The connection between titanium dioxide particles and testicular damage in male mice has already been demonstrated $[9,10]$. Wise et al. investigated relationships of testicular iron and ferritin concentrations with testicular weight and sperm production in boars [11]. Effect of the iron also examined Akalin et al. and the result was, that iron had a negative effect on sperm of rams [12]. There are several studies of the presence of different form of the metallic elements in the human body. The aim is also to investigate the effect of metals on the human body, especially effect to male infertility in this case. Some of the present metallic elements may also be in the form of nano-sized particles. For example, Perera et al. investigated the effect of iron on human sperm. It was found that DNA semen of men with homozygous $\beta$ thalassaemia major, who were exposed to high doses of iron, showed damage [13]. Klein et al. measured the concentration of aluminum in the semen of 62 patients. Patients with oligozoospermia had a statistically higher aluminum concentration on the semen than reference group [14]. Roychoudhury et al. discovered that the copper NPs are capable of generating oxidative stress in vitro, thereby, they might lead to reproductive toxicity [15]. Kumar et al. studied risks of chrome and there was no observed effect of chromium on semen volume, $\mathrm{pH}$ or sperm count, motility and viability. However, a marked increase in morphologically abnormal sperm was observed in exposed men [16]. Wu et al. found that zinc could inhibit hydrogen peroxide-induced damage of sperm in assisted reproductive technology. However, the presence of zinc alone in the culture medium can also decrease the sperm quality without addition of peroxide [17]. Danadevi et al. recognized the effect of nickel and chromium on the sperms of welders. It was found welders had less sperms and the sperms were abnormally shaped compared to the control group [18].

The aim of this pilot study was to detect micro- and nanometric metal-based particles in the ejaculate of a group of patients diagnosed with infertility.

\section{EXPERIMENTAL PART}

\subsection{Sample preparation}

The original ejaculate sample was mixed with PBS (phosphate buffered saline) to a maximum of 20 million sperms / $\mathrm{ml}$. The diluted sample was mixed with agarose and added in a volume of 10-12 $\mu \mathrm{l}$ to the centre of the ring on a slide and covered with a coverslip. After agarose solidified, the coverslip was removed. Denaturation and lysis solutions were used for further treatment. Finally, the sample was dehydrated with $70 \%$ alcohol and incubated in $100 \%$ alcohol. After removal of the alcohol, the sample was let to dry. The treated sample was subsequently analyzed for the presence of micro- and nano-particles. The ejaculate samples were prepared in cooperation with the cytogenetics department, CGB Laboratory, a.s. in Ostrava - Vítkovice. 
Informed consent was obtained from all patients through this laboratory in accordance with applicable legislation. The study was performed in accordance with the Declaration of Helsinki, good clinical practice, and applicable regulatory requirements. Informed consent was obtained from all participants before initiation of any procedure.

\subsection{Analytical methods}

Prepared samples were analysed using two analytical methods. The first method was scanning electron microscopy. Samples were sputter coated with two layers of gold (POLARON SC 7640 sputter coater) to ensure their conductivity. Scanning electron microscope Quanta 450 FEG (FEI) was used for revealing of the morphology of studied samples. EDS analysis was performed with analyser APOLLO X (EDAX) and served for the determination of the presented elements. Images were taken using BSED detector (back-scattered electrons detector) at applied acceleration voltage equal to $15 \mathrm{kV}$. The second method was Raman microspectroscopy XploRA ${ }^{\mathrm{TM}}$ (HORIBA Jobin Yvon, France). Raman spectra were acquired in the whole range from 100 to $4000 \mathrm{~cm}^{-1}$. The $532 \mathrm{~nm}$ excitation laser source $(20-25 \mathrm{~mW})$ with the laser spot diameter of approximately $0.5 \mu \mathrm{m}$ allowing point analysis of particles/clusters was used. The intensity of the laser was regulated regarding to the measured sample. Mostly, a lower intensity of the laser beam was set due to the potential of damage of organic samples.

\section{RESULTS AND DISCUSSION}

The available information about an individual ejaculate samples are given in Table 1. In addition, Table 1 also shows the metal-based particles and compounds that were detected in the samples.

Table 1 Information of analysed samples and summary of detected particles and compounds

\begin{tabular}{|c|c|c|c|c|c|c|}
\hline Sample & Age & Diagnosis & $\begin{array}{c}\text { Sperm } \\
\text { count } \\
\text { (mil/ml) }\end{array}$ & $\begin{array}{c}\text { Fragmented } \\
\text { DNA (\%) }\end{array}$ & Detected elements & $\begin{array}{l}\text { Detected } \\
\text { compounds }\end{array}$ \\
\hline 1 & 30 & infertility & 8.3 & 24 & $\mathrm{Fe}, \mathrm{Al}, \mathrm{Zn}$ & - \\
\hline 2 & 30 & infertility & 106 & 47 & $\mathrm{Fe}, \mathrm{Cu}, \mathrm{Cr}, \mathrm{Zn}$ & - \\
\hline 3 & 43 & infertility & 100 & 6 & $\mathrm{Al}$ & - \\
\hline 4 & 38 & infertility & 80 & 36 & $\mathrm{Fe}, \mathrm{Al}, \mathrm{Zn}, \mathrm{Ti}$ & - \\
\hline 5 & 36 & infertility & 75 & 19 & $\mathrm{Ti}, \mathrm{Cr}, \mathrm{Ni}$ & - \\
\hline 6 & 42 & infertility & - & 14 & $\mathrm{Al}, \mathrm{Cu}, \mathrm{Ti}, \mathrm{Fe}$ & - \\
\hline 7 & 33 & infertility & 152 & 38 & $\mathrm{Al}, \mathrm{Fe}, \mathrm{Zn}, \mathrm{Ti}$ & - \\
\hline 8 & 37 & infertility & 21 & 82 & $\mathrm{Cu}, \mathrm{Fe}, \mathrm{Cr}, \mathrm{Al}, \mathrm{Ti}$ & $\mathrm{TiO}_{2}-$ Rutil, $\mathrm{CaCO}_{3}$ \\
\hline 9 & 33 & infertility & 55 & 35 & $\mathrm{Fe}$ & - \\
\hline 10 & 39 & infertility & 5 & 18 & - & - \\
\hline
\end{tabular}

The data in the Table 1 show that iron particles were detected in seven ejaculate samples and aluminium particles were detected in six samples out of evaluated ones. Concurrently, titanium was also found in half of all evaluated samples. An example of titanium-based particle found in sample 8 by SEM/EDS is shown in Figure 1. Other metals, such as chromium and copper, were detected in three samples from the studied ones. Zinc was found in four samples. As Table 1 shows, nickel was found only in one sample. The highest representation of various metals was found in the sample 8 . In this sample titanium dioxide compound was identified by using the Raman microspectroscopy (Figure 2). At the same time, count of the sperm in the sample 8 was low and the percentage of the fragmentation DNA was relatively high. 

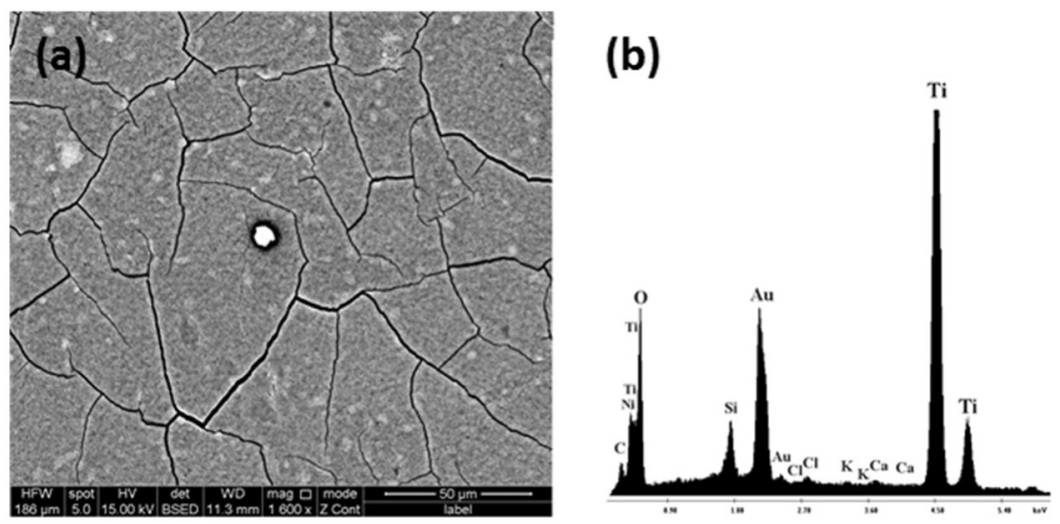

Figure 1 Example of a SEM image of the detected titanium particle (a) and the corresponding EDS spectrum (b) in sample 8

From the information given in the Table $\mathbf{1}$, we can observe a large dispersion of sperm counts per millilitre of ejaculate in studied samples. As stated in the introduction, counts of sperm below 10 million in the ejaculate may indicate a problem with fertility. Only two samples from our studied samples had this low count of sperm. Conversely, in three samples from our studied group higher count of sperm per millilitre of ejaculate (over 100 million) can be seen. This information suggests that male infertility is not caused only a low count of sperm in the ejaculate, but it can also be caused by DNA fragmentation. However, there are also cases when infertility has been diagnosed in patients with a high sperm count (more than 100 million) per millilitre and a low percent of DNA fragmentation (Table 1 - sample 3). As mentioned above, almost all of metals detected in this study have previously shown some association between their presence and male infertility. Those metals detected also in other studies were mainly liked to a reduction in the number of active sperm in the ejaculate or damage to the DNA itself [9-18].

\section{CONCLUSION}

This pilot study proved the ability to detect metal particles in the human ejaculate using selected analytical methods. All of these samples

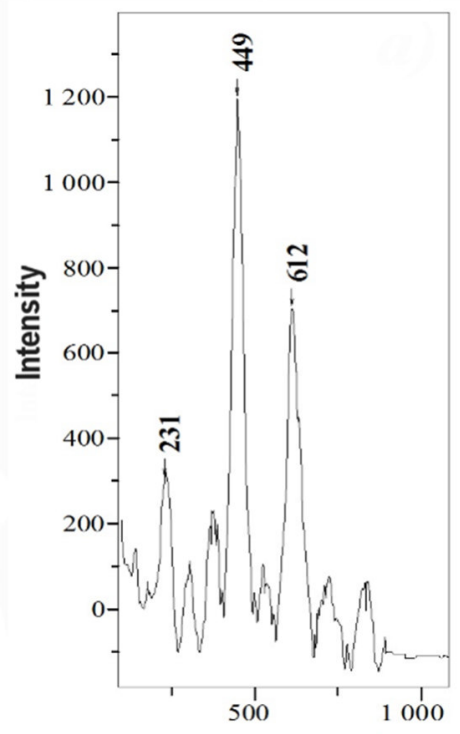

Wevenumber $\left(\mathrm{cm}^{-1}\right)$

Figure 2 Raman spectrum of the detected titanium (rutile)

in sample 8 originated from men who were diagnosed with infertility. Moreover, there were also men with normal sperm count and low DNA damage, nevertheless they suffered from infertility as well. The clarification of relationship between metal-based particles detected in the human ejaculate and infertility can help to explain infertility without somatic manifestation and consequently lead to required medical treatment. To confirm this hypothesis, it is important to analyse the samples without diagnosed infertility following this study.

\section{ACKNOWLEDGEMENTS}

This work was supported by the Ministry of Education, Youth and Sports of the Czech Republic [grant number: SP2019/56] and the ERDF (European Regional Development Fund) / ESF (European Social Fund) [grant number: CZ.02.1.01/0.0/0.0/17_049/0008441]. 


\section{REFERENCES}

[1] Male Infertility. In: The American Pregnancy Association [online]. Irving, @2018, 2017. Available from http://americanpregnancy.org/infertility/maleinfertility/.

[2] Sharpe RM. Sperm counts and fertility in men: a rocky road ahead. Science \& Society Series on Sex and Science. EMBO Rep [online]. 2012, vol. 13, iss. 5, pp. 398-403 [viewed 2019-09-25]. Available from: https://doi.org/10.1038/embor.2012.50.

[3] Male infertility. In: Andrology Australia: What every man needs to know [online]. Melbourne, 2016 [viewed 2019-09-25]. Available from: https://andrologyaustralia.org/yourhealth/male-infertility/.

[4] IRVINE, D.S., TWIGG, J., GORDON, E.L., FULTON, N., MILNE, P.A.G. and AITKEN, RJ. DNA integrity in human spermatozoa: relationships with semen quality. Journal of Andrology. 2000. vol. 21, no. 1, pp. 33-44.

[5] Assay of Sperm DNA fragmentation. In: CGB Laboratory [online]. Ostrava-Vítkovice, @2016 [viewed 2019-09-25]. Available from: http://www.pathology.cz/wp-content/uploads/2015/03/frag dna.pdf.

[6] SKOCAJ, M., FILIPIC, M., PETKOVIC, J. and NOVAK, S. Titanium dioxide in our everyday life; is it safe?. Radiology and Oncology. 2011. vol. 45, no. 4, pp. 227-247.

[7] NanoINFO. DaNa: Informationen zu Nanomaterialien und Nano-Sicherheitsforschung [online].Frankfurt a.M. [viewed 2019-09-25] Available from: https://www.nanopartikel.info/en/nanoinfo.

[8] SIMKÓ, M., NENTWITCH, M., GAZSÓ, A. and FIEDELER, U. How Nanoparticles Enter the Human Body and Their Effects There. The NanoTrust Dossiers. Vienna: Institute of Technology Assessment (ITA), 2010, no. 3, pp. 1-4.

[9] GAO, G., ZE, Y., ZHAO, X. et al. Titanium dioxide nanoparticle induced testicular damage, spermatogenesis suppression, and gene expression alterations in male mice. Journal of Hazardous Materials. 2013. vol. 258-259, pp. 133-143.

[10] GUO, L-L., XIAO-HUI, L., DING-XIA, Q., LI, G., HONG-MEI, Z., JIA-YIN L. and YUGUI, C. Effects of nanosized titanium dioxide on the reproductive system of male mice. Zhonghua nan ke xue = National journal of andrology. 2009. vol. 15 , no. 6 , pp. 517-22.

[11] WISE, T., LUNSTRA, D.D., ROHRER, G.A. and FORD, J.J. Relationships of testicular iron and ferritin concentrations with testicular weight and sperm production in boars. Journal of Animal Science. 2003. vol. 81, no. 2, pp. 503-511.

[12] AKALIN, P.P., BÜLBÜL, B., ÇOYAN, K., BAŞPINAR, N., KIRBAŞ, M., BUCAK, M.N., GÜNGÖR, Ş. and ÖZTÜRK, C. Relationship of blood and seminal plasma ceruloplasmin, copper, iron and cadmium concentrations with sperm quality in Merino rams. Small Ruminant Research. 2015. vol. 133, pp. 135-139.

[13] PERERA, D., PIZZEY, A., CAMPBELL A., KATZ, M., PORTER, J., PETROU, M., IRVINE, D.S. and CHATTERJEE, R. Sperm DNA damage in potentially fertile homozygous-thalassaemia patients with iron overload. Human Reproduction. 2002. vol. 17, no. 7, pp. 1820-1825.

[14] KLEIN, J.P., MOLD, M., MERY, L., COTTIER, M. and EXLEY, C. Aluminum content of human semen: Implications for semen quality. Reproductive Toxicology. 2014. no. 50, pp. 43-48.

[15] ROYCHOUDHURY, S., NATH, S., MASSANYI, P., STAWARZ, R., KACANIOVA, M. and KOLESAROVA, A. Copper-Induced Changes in Reproductive Functions: In Vivo and In Vitro Effects. Physiological Research. 2016. vol. 65, no. 1, pp. 11-22.

[16] KUMAR, S., SATHWARA, N.G., GAUTAM, A.K. et al. Semen quality of industrial workers occupationally exposed to chromium. Journal of Occupational Health. 2005. vol. 47, no. 5, pp. 424-430.

[17] WU, J., WU, S., XIE, Y. et al. Zinc protects sperm from being damaged by reactive oxygen species in assisted reproduction techniques. Reproductive BioMedicine Online [online]. 2015. vol. 30, iss. 4, pp. 334-339 [viewed 2019-09-25]. Available from: https://doi.org/10.1016/j.rbmo.2014.12.008.

[18] DANADEVI, K., ROZATI, R., REDDY, P.P., GROVER, P. Semen quality of Indian welders occupationally exposed to nickel and chromium. Reproductive Toxicology. 2003. vol. 17, no. 4, pp. 451-456. 